\title{
Evaluation of life quality of patients submitted to orthognathic surgery
}

\author{
Ana Catarina Alves e Silvaํ, Roberta Almeida Silveira Carvalho², Thiago de Santana Santos ${ }^{3}$, Nelson Studart Rocha ${ }^{4}$, \\ Ana Cláudia Amorim Gomes ${ }^{5}$ Emanuel Dias de Oliveira e Silva ${ }^{6}$
}

Objective: To compare changes related to self-esteem and appearance satisfaction between pre and postsurgical phases in patients undergoing orthognathic surgery and to assess the quality of life and psychosocial changes of these patients six months after surgery. Methods: A longitudinal observational qualitative study was performed. The sample comprised 15 patients with dentofacial deformities who underwent orthognathic surgery. One questionnaire and two forms were answered during pre and postoperative phases. Results: The results showed that $13.3 \%$ of patients demonstrated self-esteem improvement, especially in relation to appearance satisfaction. Improvements were also noted in social, occupational and family relationships. With regard to the assessment of quality of life, according to the World Health Organization questionnaire, the lowest improvement averages corresponded to environmental control. Conclusion: Orthognathic surgery brings along many emotional changes that should be considered before and after surgery, since the patients' psychological state may be favorable and/or unfavorable during recovery, influencing their quality of life, self-esteem and appearance satisfaction.

Keywords: Quality of life. Oral surgery. Orthodontics.

Objetivo: comparar as mudanças relacionadas à autoestima e satisfação com aparência, entre o pré-operatório e o pós-operatório, de pacientes submetidos à cirurgia ortognática, e avaliar a qualidade de vida e mudanças psicossociais desses pacientes seis meses após a cirurgia. Métodos: estudo qualitativo, de caráter observacional do tipo longitudinal, com amostra de 15 pacientes que apresentavam deformidades dentofaciais e que foram submetidos à cirurgia ortognática. Foram aplicados um questionário e dois formulários, em duas fases: uma pré-cirúrgica e outra pós-cirúrgica. Resultados: os resultados mostraram que 13,3\% dos pacientes obtiveram melhora em relação à autoestima e, principalmente, em relação à satisfação com a aparência. Foi também constatada melhoria nas relações sociais, profissionais e familiares. Em relação à avaliação da qualidade de vida segundo o questionário da Organização Mundial da Saúde, observou-se que a média mais baixa correspondeu ao domínio meio ambiente. Conclusões: a cirurgia ortognática traz consigo uma carga emocional elevada, que deve ser considerada antes e após o ato cirúrgico, pois o estado psicológico do paciente repercute em fatores favoráveis ou desfavoráveis durante a sua recuperação, influenciando de diferentes formas na qualidade de vida, autoestima e satisfação com a aparência.

Palavras-chave: Qualidade de vida. Cirurgia bucal. Ortodontia.

${ }^{1}$ MSc Student in Social Health, Federal University of Pernambuco (UFPE).

${ }^{2}$ Specialist in Endodontics, School of Dentistry of Recife (FOR).

${ }^{3} \mathrm{PhD}$ Student in Oral and Maxillofacial Surgery, School of Dentistry of Ribeirão Preto (FORP/USP).

${ }^{4} \mathrm{PhD}$ in Oral and Maxillofacial Surgery and Trauma, School of Dentistry of Pernambuco (FOP/UPE).

${ }^{5}$ Professor of Oral and Maxillofacial Surgery and Trauma, FOP/UPE.

${ }^{6} \mathrm{Head}$ of Residency in Oral and Maxillofacial Surgery and Trauma, Oswaldo Cruz University Hospital (HUOC/UPE).
How to cite this article: Alves e Silva AC, Carvalho RAS, Santos TS, Rocha NS, Gomes ACA, Oliveira e Silva ED. Evaluation of life quality of patients submitted to orthognathic surgery. Dental Press J Orthod. 2013 Sept-Oct;18(5):107-14.

Submitted: February 01, 2010 - Revised and accepted: April 12, 2010

" The authors report no commercial, proprietary or financial interest in the products or companies described in this article.

Contact address: Thiago de Santana Santos

Av. Gal. Newton Cavalcanti, 1.650 - Camaragibe/PE - CEP: 54.753-220 - Brazil E-mail: thiago.ctbmf@yahoo.com.br 


\section{INTRODUCTION}

Beauty is highly valued in society and it is considered a determining element in interpersonal relationships. Orthognathic surgery allows improvements in masticatory, phonetic and breathing functions as well as in facial esthetics, being an expressive way of raising the quality of life of people with dentofacial deformities. This surgical procedure aims to improve patients' self-esteem, esthetics and function; therefore, any facial changes resulting from the surgery can positively influence patients' personal and social life as well as their psychological state. However, physical and/or psychological complications may occur, such as nerve sensitivity or the patients' difficulty in becoming adapted to their new appearance. ${ }^{15}$

In the health field, the interest in quality of life issues is relatively recent. With regard to subjectivity, it comprises the perception of people about their own health and nonmedical aspects of their life, taking into account how people evaluate their personal situation in relation to particular quality of life parameters. Most studies focus on quantitative results concerning the treatment of deformities while only a few focus on the patients' point of view, qualitatively evaluating them. ${ }^{24}$

According to Fleck et al, ${ }^{8}$ quality of life was defined by the Quality of Life Group of the World Health Organization as "an individual's perception of their situation in life, considering the culture context and value system on which they live and in relation to their goals, expectations, standards and concerns." Despite the growing importance of quality of life assessments in different medical areas, there had not been any assessment tool developed within a cross-cultural perspective and which could be used internationally. Therefore, a 100-question assessment questionnaire was initially created (WHOQOL-100). ${ }^{23}$

The need for shorter forms that require little time to be filled out, yet offering satisfactory psychometric readings, was the main reason why the Quality of Life Group of the World Health Organization decided to create an abbreviated version (WHOQOL-bref) of the initial questionnaire (WHOQOL-100). The WHOQOL-bref comprises 26 questions, two questions on general quality of life issues and 24 questions on specific subjects which characterized the original questionnaire. A confirmatory factor analysis was performed to analyze four aspects of which the WHOQOL-bref is comprised of: physical, psychological, social relationships and environmental. ${ }^{18}$
The aim of this study was to compare the changes related to self-esteem and appearance satisfaction between pre and postsurgical phases in patients undergoing orthognathic surgery and to evaluate the quality of life of these patients six months after the surgery.

\section{MATERIAL AND METHODS}

This study was qualitative, analytical and comprised an observational, longitudinal research. Its target population consisted of 15 randomly selected patients who presented dentofacial deformities and underwent corrective orthognathic surgery at the Oral Surgery and Maxillofacial Trauma division of the Oswaldo Cruz University Hospital, at the University of Pernambuco (HUOC/UPE). Patients with cleft lip and palates as well as other uncontrolled pathologies were not included.

This study had a minimum follow-up period of six months and it was carried out in two different stages: 1) at the presurgical phase, performed on the day of the patients' hospitalization, 2) at the postoperative phase, performed 6 months after the surgery.

A questionnaire and two forms were used to collect the data. An informed consent form and an approval protocol issued by the Ethics Committee of the University of Pernambuco (number 054/07) were attached to the questionnaires to inform the patients and/or their guardian about their participation in the research. A written authorization was requested as well.

\section{Presurgical phase}

At this stage, we applied a self-administered questionnaire (answered by the patients) which consisted of eleven multiple choice and/or open-ended questions. Their purpose was to assess the satisfaction of patients with their appearance and social relationships before the surgery (Fig 1).

\section{Postsurgical phase}

At this stage, two forms were applied. Form I consisted of fifteen multiple choice and/or openended questions assessing the same variables.

Form II consisted of the WHOQOL-Bref questionnaire validated by the World Health Organization (WHO) to assess quality of life (Fig 2).

For data analysis, absolute and percentile distributions, as well as statistic measurements, were obtained. The McNemar's test, the Fisher exact test (provided that 
the conditions for using the chi-square test were not confirmed) and the Student $t$ test with equal and unequal variables (inferential statistical techniques) were applied to those measurements. The verification concerning the hypothesis of equality of variances was performed using the Levene's F test. Data were imported to an Excel spreadsheet and statistical calculations were carried out using SPSS 13.0. The method error considered for the statistical tests was of $5.0 \%$.

\section{RESULTS}

The age of the subjects ranged from 17 to 35 years, with a mean value of 25 years old, a 5.70 year standard deviation and a variation coefficient of $22.80 \%$.

The prevalent surgical procedures were "two-jaw corrections" (26.7\%), followed by "maxillary advancement" (13.3\%) and "mandibular setback" (13.3\%). "Bite problems" were the most frequent reported reasons for seeking treatment, corresponding to 40\%.

No patient had undergone psychological or speech therapy before or after the surgery. Most patients claimed to have a good self-esteem before and after the surgery. $13.3 \%$ of patients who had claimed to have fair self-esteem claimed to have a good self-esteem 6 months after the surgery (Table 1).

Before the surgery, a little more than half (53.3\%) of patients claimed to be little satisfied with their own appearance, $40.0 \%$ claimed to be satisfied and only one patient claimed to be very satisfied. After the surgery, $33.3 \%$ out of $53.3 \%$ of patients who had claimed to be "little satisfied" became "satisfied", and 20\% claimed to be "very satisfied".

Regarding social relationships, $64.3 \%$ reported that their professional relationships continued the same after surgery, 21.4\% reported slight improvements and $14.3 \%$ reported significant improvements. Moreover, $60.0 \%$ of patients reported that social relationships continued the same after surgery, 20.0\% reported slight improvements and $20.0 \%$ reported significant improvements in social relationships after surgery.

When asked about their satisfaction in regards to the surgical outcomes (Table 2), 93.3\% of patients stated that the surgical outcomes met their expectations and two-thirds (66.7\%) would undergo surgery again.

\footnotetext{
Research control:

Number:

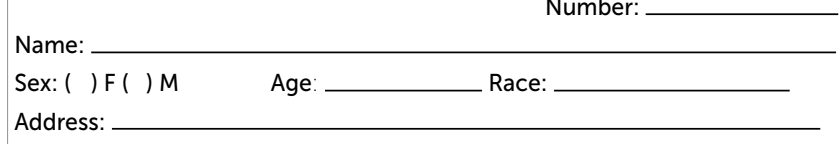

Phone: (_)

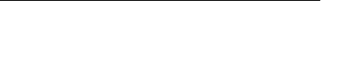

Educational background:

\begin{tabular}{|c|c|c|}
\hline$\square 1^{\circ}$ Incomplete & $\square 2^{\circ}$ Incomplete & $\square 3$ Incomplete \\
\hline$\square 1^{\circ}$ Complete & $\square 2^{\circ}$ Complete & $\square$ 3ㅇ Complete \\
\hline
\end{tabular}

Occupation:

$\square 2$ Complete

$\square$ 3 Complete

What type of surgery will you go through?

$\square$ Maxillary advancement

$\square$ Maxillary setback

$\square$ Superior repositioning of the maxilla $\square$ Inferior repositioning of the maxilla

$\square$ Segmental maxillary surgery $\square$ Mandibular advancement

$\square$ Mandibular setback $\square$ Mentoplasty

$\square$ Combined maxillary and mandibular surgery $\square$ Maxillary expansion

What made you seek treatment?

$\square$ I thought I needed. $\quad \square$ My relatives though I needed

$\square$ My friends thought I needed $\square$ My dentist though I needed.
}

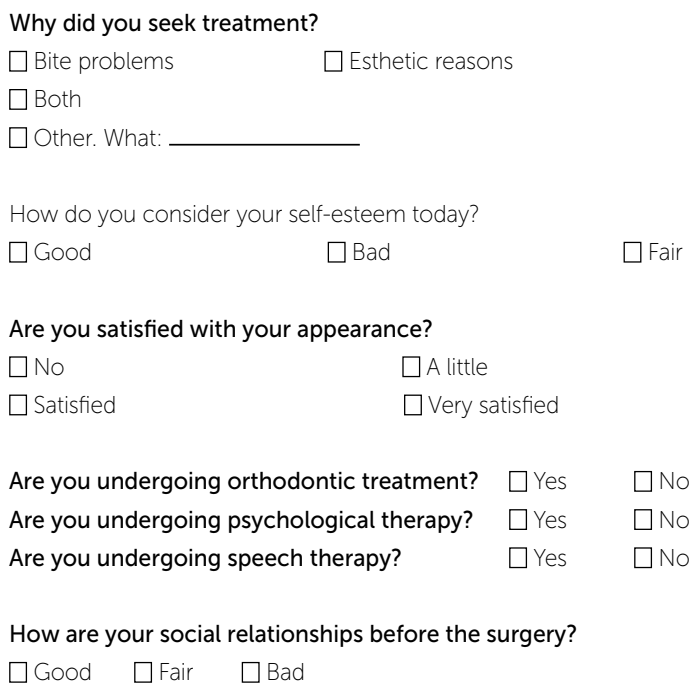

Figure 1 - Self-administered questionnaire applied at presurgical phase. 
Most patients (86.7\%) would recommend surgery to their family members, however, one third (33.3\%) claimed to have postsurgical complaints and when asked about the main reasons concerning postsurgical complaints, the answers were: 24-hour postsurgical recovery $(66.7 \%)$, difficulty for eating $(60.0 \%)$, one- week postsurgical recovery $(46.7 \%)$ and maxillomandibular immobilization with rubber bands (33.3\%).

With regard to the statistics on quality of life concerning each of the four areas of the WHOQOLbref, the results demonstrate that the lowest mean was recorded for environmental area (70.22), ranging from 81.50 to 85.78 in the other three areas. However, except for two patients in the physical and psy- chological areas and one patient in each of the other areas, all the others had their quality of life classified as high (Tables 3 and 4).

Assessments on the quality of life according to the WHO questionnaire showed that the mean value was higher among patients who went through maxillary surgery than those patients who underwent mandibular surgery, according to physical and environmental areas (Fig 3). The opposite occurred in the psychological and social relationships areas, revealing that the greatest difference was recorded in the physical area $(88.50$ $x$ 78.00), followed by the social relationships area $(88.00 \times 81.33)$. However, the only significant difference was recorded for the physical area $(\mathrm{p}<0.05)$.

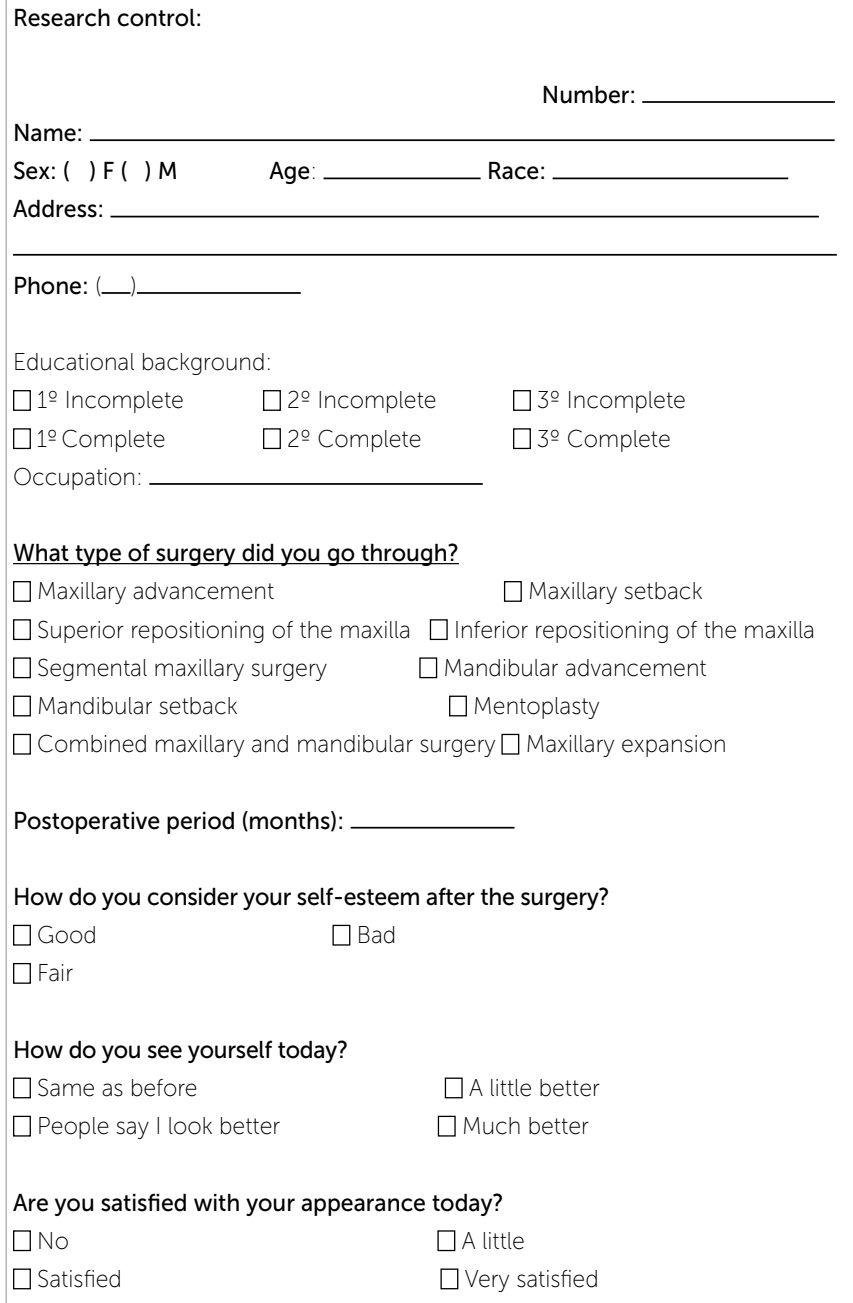

Figure 2 - Self-administered questionnaire applied at postoperative phase. 
Table 1 - Self-esteem evaluation before and after the surgery.

\begin{tabular}{|c|c|c|c|c|c|c|c|}
\hline \multirow{3}{*}{ Self-esteem (before) } & \multicolumn{6}{|c|}{ Self-esteem (after) } & \multirow{3}{*}{ PValue } \\
\hline & \multicolumn{2}{|c|}{ Good } & \multicolumn{2}{|c|}{ Fair } & \multicolumn{2}{|c|}{ TOTAL } & \\
\hline & $n$ & $\%$ & n & $\%$ & $n$ & $\%$ & \\
\hline Good & 12 & 80.0 & - & - & 12 & 80.0 & $p^{\star}=0.500$ \\
\hline Fair & 2 & 13.3 & 1 & 6.7 & 3 & 20.0 & \\
\hline TOTAL & 14 & 93.3 & 1 & 6.7 & 15 & 100.0 & \\
\hline
\end{tabular}

* McNemar test was applied.

Table 3 - Quality of life score assessment for each area according to the postsurgical evaluation.

\begin{tabular}{ccccc}
\hline \multirow{2}{*}{ Statistics } & \multicolumn{4}{c}{ Area } \\
\cline { 2 - 5 } & Physical & $\begin{array}{c}\text { Psycho- } \\
\text { logical }\end{array}$ & $\begin{array}{c}\text { Social rela- } \\
\text { tionships }\end{array}$ & $\begin{array}{c}\text { Environ- } \\
\text { mental }\end{array}$ \\
\hline Mean & 81.50 & 80.59 & 85.78 & 70.22 \\
\hline Standard deviation & 8.12 & 6.20 & 12.31 & 7.91 \\
\hline Variation coefficient & 9.96 & 7.69 & 14.35 & 11.26 \\
\hline Minimum & 67.50 & 66.67 & 53.33 & 56.67 \\
\hline Maximum & 95.00 & 88.89 & 100.0 & 83.33 \\
\hline
\end{tabular}

Table 4 - Quality of life score assessment for each area according to the postsurgical evaluation.

\begin{tabular}{ccccccccc}
\hline & \multicolumn{8}{c}{ Area } \\
\cline { 2 - 10 } Statistics & Physical & $\begin{array}{c}\text { Psychologi- } \\
\text { cal }\end{array}$ & $\begin{array}{c}\text { Social rela- } \\
\text { tionships }\end{array}$ & $\begin{array}{c}\text { Environmen- } \\
\text { tal }\end{array}$ \\
& $n$ & $\%$ & $n$ & $\%$ & $n$ & $\%$ & $n$ & $\%$ \\
\hline Low & 2 & 13.3 & 2 & 13.3 & 1 & 6.7 & 1 & 6.7 \\
High & 13 & 86.7 & 13 & 86.7 & 14 & 93.3 & 14 & 93.3 \\
\hline TOTAL & 15 & $\mathbf{1 0 0 . 0}$ & $\mathbf{1 5}$ & $\mathbf{1 0 0 . 0}$ & $\mathbf{1 5}$ & $\mathbf{1 0 0 . 0}$ & $\mathbf{1 5}$ & $\mathbf{1 0 0 . 0}$ \\
\hline
\end{tabular}

*(1) The highest limits for each high area were: $71.5 \%-100.0 \%$ physical, $70.9 \%-95.8 \%$ psychological, $71.1 \%-100.0 \%$ social relationships and $57.2 \%$ $93.7 \%$ environmental.

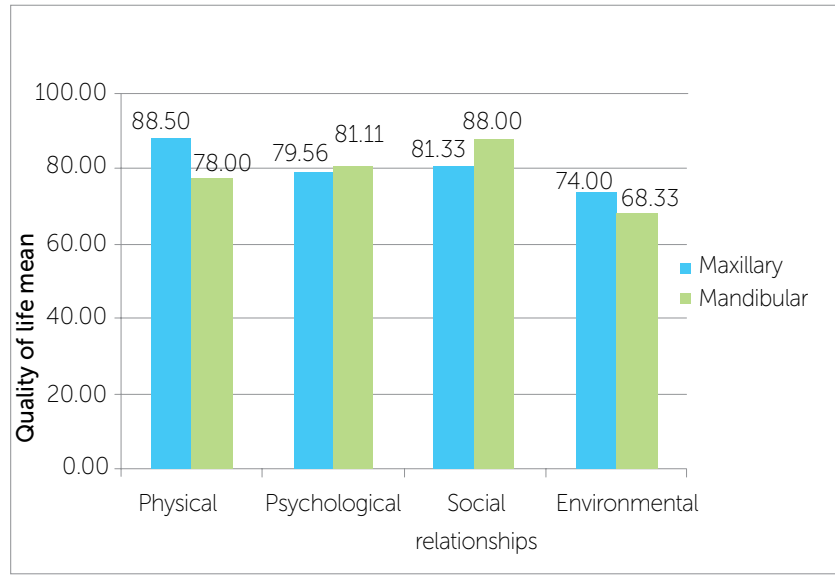

Figure 3 - Quality of life means for each area according to the type of surgery carried out.
Table 2 - Distribution of surveyed patients according to postsurgical variables.

\begin{tabular}{|c|c|c|}
\hline Variables & $\mathbf{n}$ & $\%$ \\
\hline \multicolumn{3}{|l|}{ How do you see yourself today? } \\
\hline Same as before & 1 & 6.7 \\
\hline A little better & 2 & 13.3 \\
\hline People say I look better & 1 & 6.7 \\
\hline Much better & 11 & 73.3 \\
\hline \multicolumn{3}{|l|}{ Did you get the results you expected? } \\
\hline Yes & 14 & 93.3 \\
\hline No & 1 & 6.7 \\
\hline \multicolumn{3}{|l|}{ Do you have complaints regarding the surgery? } \\
\hline Yes & 5 & 33.3 \\
\hline No & 10 & 66.7 \\
\hline TOTAL & 15 & 100.0 \\
\hline \multicolumn{3}{|l|}{ What was the most bothersome aspect of surgery? } \\
\hline Immediate presurgical phase & 1 & 6.7 \\
\hline 24-hour postoperative phase & 10 & 66.7 \\
\hline Eating issues & 9 & 60.0 \\
\hline Paresthesia & 3 & 20.0 \\
\hline Hospitalization & 1 & 6.7 \\
\hline One-week postoperative phase & 7 & 46.7 \\
\hline Maxillomandibular immobilization with rubber bands & 5 & 33.3 \\
\hline Other & 2 & 13.3 \\
\hline Basis* & 15 & \\
\hline \multicolumn{3}{|l|}{ Would you undergo surgery again? } \\
\hline Yes & 10 & 66.7 \\
\hline No & 5 & 33.3 \\
\hline \multicolumn{3}{|c|}{ Would you recommend the surgery to your family members? } \\
\hline Yes & 13 & 86.7 \\
\hline No & 2 & 13.3 \\
\hline TOTAL & 15 & 100.0 \\
\hline
\end{tabular}

* (1) If a single subject mentioned more than one bothersome factor, a basis of the percentages calculations is recorded instead of the total value.

\section{DISCUSSION}

Psychological aspects of patients going through orthognathic surgery, has just recently become target of investigation and the $\mathrm{WHO}$ questionnaires ${ }^{1,8,11,23}$ has shown to be an efficient tool to evaluate the quality of life of these individuals.

In this study, we used two forms for pre and postsurgical assessment and the WHOQOL-Bref questionnaire for postsurgical assessment, corroborating the methodology used by Modig et al. ${ }^{15}$ This questionnaire, recommended by the WHO for quality of life assessments, was the method chosen for this study because there has not been a validated questionnaire 
for assessing quality of life in orthognathic surgery issued in Portuguese as recommended by Lee et al. ${ }^{11}$

The time on which the questionnaires are applied, at pre and postsurgical phases, have been addressed in the literature. Most authors recommend that the questionnaires should be applied on the day of the presurgical orthodontic preparation and six months after the surgery. ${ }^{4,5,6,11}$ The suggestion of a six-month postsurgical phase is due to the fact that, within this period, the edema decreases, allowing a better visualization of esthetic facial and oral function changes, and the patient returns to social interaction. ${ }^{4,5,11}$ However, some questionnaires were applied six weeks or a year after the surgery, ${ }^{4,21}$ once improvements concerning the edema, neurosensory changes as well as bite and speech problems have been identified. ${ }^{15,21,26}$ Some authors recommend that the questionnaires should be applied when removing orthodontic braces or only post-surgically, with no need of applying the presurgical questionnaire. ${ }^{14}$ Despite the fact that in the studies of Sadek and Salem ${ }^{21}$ the questionnaires were applied a few days before the surgery, this study applied them a day prior to the surgery. This method had not been used in previous articles, therefore, it may have been the source of biased answers, since that day is when the patients are under extreme presurgical tension. On the other hand, the method of applying the questionnaire six months after the orthognathic surgery was also the method of analysis of several previous studies. ${ }^{4,5,6,11}$

The reasons patients seek orthosurgical treatment are, oftentimes, exclusively related to esthetics or function, and in most cases such reasons are combined. . $^{3,5,711,14,16,19,26,28,29}$ Considering that the surgical procedure may result in irreversible changes on the patients' face and personality, both specialist and family should not influence the patients' decision. Thus, the final decision to undergo surgery should come from the patients. ${ }^{10,17}$ Taking these factors into account, the results obtained in this study seemed favorable in regards to the short-term risks and complications that patients go through in order to obtain long-term benefits. Esthetic reasons alone accounted for $20 \%$ of the cases, corroborating some publications ${ }^{11,15,16}$ while disagreeing with others which observed that esthetic motivation prevailed over function. ${ }^{21,26,29}$
Patients seeking professional resources in order to improve their appearance are also seeking to recover their personal and social image. In addition, their expectations are directly related to their degree of satisfaction. ${ }^{6,27}$ Studies have reported that individuals going through orthognathic surgery, who are more concerned with esthetics aspects than others, may have psychological problems. However, the frequency of people with psychological disorders is higher when it comes to plastic surgery. ${ }^{10,15}$

The study carried out by Kiyak et a ${ }^{10}$ concluded that despite the problems related to the surgery, satisfaction was quite high at the postoperative phase: $84.2 \%$ of the subjects said they would go through surgery again and $92.3 \%$ said they would recommend it to another person. In this study, we have observed that from the fifteen subjects, $66.7 \%$ said they would go through surgery again if necessary and $86.7 \%$ said that despite some postsurgical discomfort they would recommend surgical correction to family members, corroborating previous publications. ${ }^{11,14,26}$

During the presurgical phase of this study, three $(13.3 \%)$ patients claimed to have a fair self-esteem, however, they reported that their self-esteem improved after the surgery, classifying their self-esteem as good at the postoperative phase. These factors were also observed in earlier publications. ${ }^{4,15,16,21,26,29}$

The patients' presurgical motivation, their personality, psychological state and other postoperative circumstances such as pain, edema, presence of jaw immobilization, temporary or permanent anesthesia and difficulty eating, are considered as reference to assess the degree of the patients' satisfaction. A detailed and careful presurgical planning and a proper surgical execution are crucial factors for a successful treatment. It is necessary to know each patient individually and the reasons why they are seeking treatment because, oftentimes, facial anomalies or discrepancies can only be addressed through orthognathic surgery. ${ }^{2,19}$

Among the patients evaluated in this study, 33.3\% reported surgical complaints. Sixty percent of patients who had difficulty adjusting a liquid/soft diet, and three patients reported weight loss ranging from 5 to $10 \mathrm{~kg}$ a month after the surgery. All patients in this study wore orthodontic rubber bands during the postsurgical phase, removing them only for eating and brushing. It is common for patients to lose weight after 
orthognathic surgery due to the decrease in the masticatory function, even when there is no jaw immobilization with rubber bands. Thus, it can be suggested that this difficulty adapting to new eating habits observed in this study may be attributed to the surgery or to the severity of dentofacial deformity, corroborating the findings of Araújo ${ }^{2}$ and Ribas et al. ${ }^{19}$

The sample of this study is heterogeneous since the patients selected had not only transverse jaw deformities, but also Classes II and III skeletal deformities. On the other hand, this method is used by several studies that qualitatively evaluate different individuals with deformities aiming at increasing the sample size. , $10-15,17,21,26^{-}$ However, the homogeneity of dentofacial deformities is recommended by some authors, ${ }^{16,27,29}$ since it reduces survey discrepancies, i.e., patients who have large asymmetric facial deformities will show noticeable esthetic facial changes, or individuals with transverse jaw deficiencies who only undergo surgically assisted rapid expansion of maxilla will show minimal changes.

It is recognized that facial changes significantly change the patients' facial appearance and can change the life of an individual in various ways. This has been noticed through the growing number of patients seeking surgical treatment for correcting dentofacial deformities in the last few years. ${ }^{25}$ Based on oncological and chronic diseases, strong concerns have been raised on the increase in life expectancy. ${ }^{18}$ Thus, the development of means to measure the quality of life of these patients has been a challenge for researchers, since they must be able to verify whether these interventions meet the desired goals. ${ }^{22}$ The results obtained in this study showed improvements in the quality of life of patients after orthognathic surgery as well as improvements related to psychosocial factors. Many patients reported that a few months after the surgery they could observe mainly favorable esthetic results which contributed to improvements in self-esteem and favored social and professional relationships. Moreover, the care and attention received from the patients' family members during the recovery process improved their proximity and contributed to unify the family bonds even more.

According to Ribeiro, ${ }^{20}$ speech therapy acts in regulating the TMJ muscles and the stomatognathic functions and in reducing the rate of dentofacial deformity relapse after surgery. Although the Oswaldo Cruz University Hospital offers speech and psycho- logical therapy services, no patient has been treated by those services at presurgical and postsurgical phases. Despite the fact that the importance of a multidisciplinary approach has been highlighted in the literature, especially with regard to patients undergoing orthognathic surgery, this integration does not often occur, corroborating this study. Therefore, the need for a multidisciplinary team should be emphasized due to its immeasurable value in the rehabilitation process, and, as a consequence, the well-being of the patient.

Patients seeking professional resources to address a health deficiency are not only pursuing cure, but also acceptance, understanding, support and affection towards emotionally triggered conditions. ${ }^{12,25}$ Moreover, patients undergoing surgical procedures have significant psychological reactions such as fear, anxiety and expectations that could hinder their recovery and the way they cope with the surgical situation.

Some characteristics of the patients' mental health should be assessed prior to surgery, including depression, anxiety, panic, aggression, drug and alcohol use, problems in school as well as family and social relationships. The overview of these factors may give an insight into the psychological and emotional capacity of the patients undergoing orthognathic surgery. ${ }^{3}$

Additionally, it is important to know the patients' expectations since the less anxiety a patient presents, the better the chance of success and postsurgical satisfaction. Factors such as pessimism, anxiety and low social support lead to higher risks for problems. ${ }^{10,13}$ Before elective surgeries, a sincere communication between the surgeon and the patient is of paramount importance as it enables the establishment of trust, allowing the patient to participate in discussions regarding the risks and benefits of the surgery; both postsurgical recovery and lifestyle..$^{2,15}$

We recognize that the low number of subjects and the heterogeneity concerning the types of dentofacial deformities as well as the surgeries that have been carried out are some of the limitations of this study and may have influenced the results.

Unlike orthodontic treatment, which produces gradual changes in dentofacial structure when performed alone, orthognathic surgery causes sudden changes. These physical and psychological changes can be so drastic that they may lead the patients to either sudden satisfaction or regret. 


\section{CONCLUSION}

When it comes to surgical-orthodontic treatment, esthetic results are considered important motivators influencing the surgical decision making. The main objective of dialogue between specialist and patient is to define what dissatisfies the latter, allowing the surgeon to establish a bond of trust that allows the patient to participate in discussions concerning the surgical risks and benefits .

The need for orthognathic surgery brings along many emotional changes that should be considered before and after the surgery, since the patients' psychological state may be favorable and/or unfavorable during recovery, influencing their quality of life, selfesteem and appearance satisfaction.

\section{REFERENCES}

1. Andrade ER, Sousa ER, Minayo MCS. Intervenção visando a auto-estima e qualidade de vida dos policiais civis do Rio de Janeiro. Ciênc Saúde Coletiva. 2009:14(1):275-85

2. Araújo A. Cirurgia ortognática. 1a ed. São Paulo: Ed. Santos; 1999

3. Bellucci CC, Kapp-Simon KA. Psychological considerations in orthognathic surgery. Clin Plast Surg. 2007:34(3): e11-16.

4. Choi WS, Lee S, McGrath C, Samman N. Change in quality of life after combined orthodontic-surgical treatment of dentofacial deformities. Oral Surg Oral Med Oral Pathol Oral Radiol Endod. 2010;109(1):46-51.

5. Cunningham SJ, Garratt AM, Hunt NP. Development of a condition-specific quality of life measure for patients with dentofacial deformity: II. Validity and responsiveness testing. Community Dent Oral Epidemiol. 2002;30(2):81-90

6. Cunningham SJ, Hunt NP, Feinmann C. Psychological aspects of orthognathic surgery: a review of the literature. Int J Adult Orthodon Orthognath Surg. 1995:10(3):159-72.

7. Dervis E, Tuncer E. Long-term evaluations of temporomandibular disorders in patients undergoing orthognathic surgery compared with a control group. Oral Surg Oral Med Oral Pathol Oral Radiol Endod. 2002 Nov;94(5):554-60.

8. Fleck MPA, Louzada S, Xavier M, Chachamovich E, Vieira G, Santos L, et al. Aplicação da versão em português do instrumento abreviado de avaliação da qualidade de vida "WHOQOL-bref". Rev Saúde Pública. 2000;34(2):178-83.

9. Jensen $\mathrm{SH}$. The psychosocial dimensions of oral and maxillofacial surgery: a critical review of the literature. J Oral Surg. 1978:36(6):447-53.

10. Kiyak HA, West RA, Hohl T, McNeill RW. The psychological impact of orthognathic surgery: a 9-month follow-up. Am J Orthod. 1982;81(5):404-12.

11. Lee S, McGrath C, Samman N. Impact of orthognathic surgery on quality of life. J Oral Maxillofac Surg. 2008;66(6):1194-9.

12. Lovius BB, Jones RB, Pospisil OA, Reid D, Slade PD, Wynne TH. The specific psychosocial effects of orthognathic surgery. J Craniomaxillofac Surg. 1990:18(8):339-42.

13. MacGregor FC. Patient dissatisfaction with results of technically satisfactory surgery. Aesthetic Plast Surg. 1981:5(1):27-32

14. Meade EA, Inglehart MR. Young patients treatment motivation and satisfaction with orthognathic surgery outcomes: the role of "possible selves". Am J Orthod Dentofacial Orthop. 2010;137(1):26-34.

15. Modig M, Andersson L, Wårdh I. Patients' perception of improvement after orthognathic surgery: Pilot study. Br J Oral Maxillofac Surg. 2006:44(1):24-7. Epub 2005 Sep 12.

16. Nicodemo D, Pereira MD, Ferreira LM. Cirurgia ortognática: abordagem psicossocial em pacientes Classe III de Angle submetidos à correção cirúrgica da deformidade dentofacial. Rev Dental Press Ortod Ortop Facial. 2007:12(5):46-54
17. Ponzoni D, Engers MEA, Oliveira MG, Puricelli E. Percepções, expectativas e manifestações de pacientes submetidos à cirurgia ortognática. RBC. 2006:4:244-50

18. Ramos-Cerqueira ATA, Crepaldi AL. Quality of life in chronic pulmonary diseases: conceptual and methodological aspects. J Pneumol. 2000;26(4):207-13.

19. Ribas MO, Reis LFG, França BHS, Lima AAS. Cirurgia ortognática: orientações legais aos ortodontistas e cirurgiões bucofacial. Rev Dental Press Ortod Ortop Facial. 2005:10(6):75-83.

20. Ribeiro MC. Atuação fonoaudiológica no pré e pós-operatório em cirurgia ortognática. J Bras Fonoaudiol. 1999:1:61-8.

21. Sadek H, Salem G. Psychological aspects of orthognathic surgery and its effect on quality of life in Egyptian patients. La Revue de Santé de la Méditerranée Orientale. 2007:13(1):150-9

22. Salvadori AM, Lamas JLT, Zanon C. Desenvolvimento de instrumento de coleta de dados de enfermagem para pacientes com câncer de pulmão em quimioterapia ambulatorial. Esc Anna Nery Rev Enferm. 2008:12(1):130-5.

23. Seidl EMF, Zannon CMLC, Troccoli BT. Pessoas vivendo com HIV/AIDS: enfrentamento, suporte social e qualidade de vida. Psicol Reflex Crit 2005;18(2):188-95

24. Seidl EMF, Zannon CMLC. Qualidade de vida e saúde: aspectos conceituais e metodológicos. Cad Saúde Pública. 2005;20(2):580-8

25. Souza LCM, Silveira ME, Cappellette M, Alael MG. Cirurgia ortognática e Ortodontia. 1a ed. São Paulo: Ed. Santos; 1998

26. Türker N, Varol A, Ögel K, Basa S. Perceptions of preoperative expectations and postoperative outcomes from orthognathic surgery: Part l: Turkish female patients. Int J Oral Maxillofac Surg. 2008;37(8)710-5

27. Veronez FS, Tavano LDA. Modificações psicossociais observadas pós-cirurgia ortognática em pacientes com e sem fissuras labiopalatinas. Arq Ciênc Saúde. 2005:12(3):133-7.

28. Westermark A, Shayeghi F, Thor A. Temporomandibular dysfunction in 1.516 patients before and after orthognathic surgery. Int J Adult Orthodon Orthognath Surg. 2001;16(2):145-51.

29. Zhou YH, Hagg U, Rabie AB. Concerns and motivations of skeletal Class III patients receiving orthodontic-surgical correction. Int J Adult Orthodon Orthognath Surg. 2001;16(1):7-17. 